Relations industrielles

Industrial Relations

\title{
An Assessment of Worker Reaction to their Union and Employer \\ Post-Strike
}

\author{
A Canadian Experience
}

Evaluación de la reacción de los trabajadores frente a sus

sindicatos y sus empleadores después de la huelga

Una experiencia canadiense

\section{Une évaluation de la réaction après-grève des travailleurs à \\ l'égard de leur syndicat et de leur employeur \\ une expérience canadienne}

Kimberly Chaulk et Travor C. Brown

Volume 63, numéro 2, 2008

URI : https://id.erudit.org/iderudit/018574ar

DOI : https://doi.org/10.7202/018574ar

Aller au sommaire du numéro

Éditeur(s)

Département des relations industrielles de l'Université Lava

ISSN

0034-379X (imprimé)

1703-8138 (numérique)

Découvrir la revue

Citer cet article

Chaulk, K. \& Brown, T. C. (2008). An Assessment of Worker Reaction to their Union and Employer Post-Strike: A Canadian Experience. Relations industrielles / Industrial Relations, 63(2), 223-245. https://doi.org/10.7202/018574ar
Résumé de l'article

Le cadre de référence d'analyse des systèmes de relations industrielles proposé d'abord par Dunlop (1958) demeure le coeur de l'enseignement et de la recherche de l'approche « système » de Craig (1967, voir également Craig et Solomon, 1996). Ce dernier s'inspire du cadre de référence des systèmes de Dunlop et il a été intensément utilisé pour l'étude des enjeux des relations du travail au Canada (voir Gunderson, Ponack et Taras, 2005). Dans le modèle de Craig, on se souvient que les grèves et les lockouts sont considérés comme des mécanismes de conversion d'intrants en extrants. Comme tel, Craig suggère qu'une grève est un mécanisme retenu pour convertir des intrants internes, tels que des objectifs, des valeurs et du pouvoir, en extrants ou en résultats de caractère organisationnel, tels que la reconnaissance du syndicat, la négociation de l'effort à fournir contre rémunération et la sécurite d'emploi. De plus, le modèle de Craig démontre que ces résultats se relient en retour aux intrants externes par le biais d'une boucle de rétroaction, créant ainsi un flux d'effets qui retournent dans le système des relations industrielles. Ce qui importe le plus, c'est que le modèle indique qu'une grève système des relations industrielles. Ce qui importe le plus, c'est que le modèle indique qu'une grève de relations industrielles. Alors, une grève exerce une influence sur la relation d'emploi.

Encore qu'une grande part du travail de recherche et d'enseignement eu égard aux grèves a aborde les enjeux d'ordre économique et politique associés aux grèves (voir les revues effectuées par Gunderson et al., 2005, Franzosi, 1989). Un effort plutôt limité de recherche dans le domaine des relations industrielles s'est intéressé aux enjeux psychologiques inhérents aux grèves. Il est évident que l'enseignement en psychologie organisationnelle ou en sciences du comportement adopte une position critique à l'endroit d'un sujet tel que l'impact d'une grève, plus précisément celui qui traite des réactions des travailleurs. Alors, cette étude-ci a analysé l'effet d'une grève en recourant à des mesures habituellement retenues dans le domaine de la psychologie organisationnelle, principalement celles qui servent à apprécier le degré de satisfaction au travail, de satisfaction à l'endroit de la direction, le degré d'implication organisationnelle, le degré de satisfaction quant au climat de travail, enfin le degré d'engagement syndical.

Des questionnaires ont été expédiés à environ 700 membres d’un syndicat qui ont pris part à une longue grève de cinq mois dans le secteur des communications. Des membres du syndicat $(n=187)$ ont complété le questionnaire en se prononçant sur cinq types d'échelles : l'engagement à l'endroit de l'organisation, la satisfaction au travail, la satisfaction quant au climat de travail, la satisfaction à l'endroit de la direction et l'engagement syndical, cela huit mois après la grève. Nous avons demandé aux participants de répondre à deux ensembles de questions pour chacune des mesures, principalement sur la manière dont ils voyaient les choses actuellement et comment ils voyaient les principalement sur la manière dont ils voyaient les choses actuellement et comment ils voyaient les
choses avant la grève. Les deux mesures avant et après la grève ont été prises au cours d'une seule et même enquête.

Des tests « $t$ " arrangés par paires ont permis de constater que la grève avait un impact négatif sur les réactions des travailleurs à la fois à l'endroit du groupe des dirigeants et de leur syndicat sur les cinq mesures. Des analyses de régression additionnelles et exploratoires sur les cinq mesures (en retenant l'ancienneté, le genre et une mesure prégrève appropriée) suggèrent que les travailleurs de sexe l'ancienneté, le genre et une mesure prégrève appropriée) suggèrent que les travailleurs de sexe masculin et les plus jeunes font part de réactions plus positives que les femmes et les travailleurs plu âgés. La conclusion pratique de cet essai est que les effets négatifs des grèves peuvent se transposer
(et ils le font) dans le lieu de travail en termes de réactions d'un travailleur à l'endroit de son syndicat et de son employeur. D'un point de vue théorique, les conclusions de ce travail permettent de croire que les travaux de recherche effectués sur la grève et les modèles retenus devraient être élargis de façon à inclure l'examen d'enjeux liés à la réaction des travailleurs.
Tous droits réservés @ Département des relations industrielles de l'Université Laval, 2008
Ce document est protégé par la loi sur le droit d'auteur. L’utilisation des services d’Érudit (y compris la reproduction) est assujettie à sa politique d'utilisation que vous pouvez consulter en ligne.

https://apropos.erudit.org/fr/usagers/politique-dutilisation/ 


\title{
An Assessment of Worker Reaction to their Union and Employer Post-Strike
}

\section{A Canadian Experience}

\author{
Kimberly Chaulk \\ Travor C. Brown
}

\begin{abstract}
Union members $(n=187)$ completed surveys assessing five affective measures (organizational commitment, job satisfaction, work climate satisfaction, management satisfaction, and union commitment) following a five-month long strike. Paired t-tests (using retrospective questions where participants assessed pre and post-strike affect on a single survey) found that the strike had a negative impact on worker reactions to both their management group and their union across all five measures. The significance of this study is that the negative effects of strikes can, and do, carry over into the workplace in terms of worker affect towards their union and employer. From a theoretical perspective, these findings are consistent with the IR systems' concept of a feedback loop and suggest that future strike research and theories should be expanded to examine issues related to worker reaction.
\end{abstract}

Almost 50 years after Dunlop (1958) proposed the industrial relations (IR) systems framework, it continues to be central to mainstream IR

- Chaulk, K., and T. C. Brown, Faculty of Business, Memorial University, St. John's, Newfoundland, travorb@mun.ca

- Note that a preliminary version of this paper was presented at the 2006 Annual Meeting of the Canadian Industrial Relations Association. The authors thank Gordon Cooke, Amy Warren, Kate Dupré and the anonymous reviewers for their helpful comments on earlier versions of this paper. This study was funded in part by a SSHRC grant to the second author. The paper is based in part on the first authors' Master of Employment Relations project, supervised by the second author, while she was a student at Memorial University. 
teaching and research (Gunderson, Ponak and Taras, 2005; Hebdon and Brown, 2007; Meltz and Adam, 1993; Pierce and Bentham, 2007). Craig's systems approach (1967; see also Craig, 1988; Craig and Solomon, 1996) is grounded in Dunlop's systems framework and has been extensively used to examine IR issues in Canada. Craig's model provides a more systematic approach to IR issues than that of Dunlop and can be used to examine the temporal effect though the feedback loop. In essence, Craig's model proposes that external inputs from the environment (e.g., legal, economic, political, etc.) impact the actors of the IR system (e.g., labour, management, government) and that through a series of conversion mechanisms (e.g., collective bargaining, third-party interventions, etc.) the parties convert the external inputs as well as the internal inputs (e.g., the goals and values of the actors) into both organizational (e.g., management and union rights) and worker-oriented (e.g., wages, due process, etc.) outputs. These outputs can then, thorough a feedback loop, influence the actors.

In Craig's model, strikes are both conversion mechanisms and outputs of the IR system. As such, Craig's model indicates that a strike (when used as conversion mechanism to achieve union goals) impacts the outputs of the IR system (e.g., wages, etc.) More specifically, we believe that the model suggests that strikes would impact the worker-oriented output of employee affect. Additionally, as strikes are an output of the IR system, they can also impact the actors of the system via the feedback loop. Just as Craig and Solomon (1996) argue that the feedback loop shows how the output of satisfactory wages can positively effect worker morale (i.e., affect) and productivity, we assert that the feedback loop can be used to show how the output of a strike can positively, or negatively, impact worker reactions towards their union and employer. Thus, we assert that the systems model provides the foundation for our belief that strikes (whether they are seen as conversion mechanisms or outputs) impact worker affect.

Even though strikes can be argued to impact worker affect, much of the research and teaching concerning strikes has examined the economic and policy issues associated with work stoppages (see Franzosi, 1989; Gunderson et al., 2005). For example, economic research has historically examined issues such as strike incidence and duration (Campolieti, Hebdon and Hyatt, 2005), the determinants of strikes (Cramton and Tracy, 1994), and the impact of strikes on employment (Rao, 2000).

Striking workers also face economic impacts from strikes as they are not receiving a paycheck and have limited access to funds, with the exception of strike pay. However, employees are faced with more than economic factors after a strike. Research has also shown that strikes can negatively impact workers' employment experience and psychological wellbeing. For example, Nicholson and Kelly (1980) indicate that a strike can 
cause several organizational changes and these changes may significantly impact the employment relationship once workers return to their jobs. For example, labour disputes may bring about workplace changes, which in turn, may create a different relationship between management and employees. As pointed out in a practitioner's journal, actions taken during the strike (e.g., verbal abuse) may result in the employment relationship being negatively impacted (Herald, 2002).

In terms of the psychological well-being of striking workers, Barling and Milligan (1987), in a study examining the impact of a 22-day labour dispute showed that strikes can have negative psychological consequences. Their results revealed that workers' negative perception of industrial relations events (i.e., strikes) predicted negative changes in psychological well-being (i.e., as assessed using a general health questionnaire) both two and six months after the strike. Thus, we argue that if an employee suffers psychologically because of a labour dispute, their reactions towards work, their union and their employer could also be negatively impacted. For example, pressures and stress from the dispute may cause employees to resent their workplace, union and/or management once they return to work.

While the preceding suggests that striking workers face potentially negative psychological and workplace experiences, we could find limited examination of how workers' affective relationship towards both union and management could be impacted by a strike. As we discuss later in the paper, the few studies we did find faced limitations such as the lack of a true work stoppage (Beauvais, Scholl and Cooper, 1991), an examination of worker affect when the workers being surveyed were not directly involved in the strike (i.e., their co-workers were on strike; Carmel et al., 1988; ShohamYakubovich et al., 1989), and the use of affect measures assessed during (Lee, 2004) or post (Barling and Milligan, 1987) strike with no consideration of how workers felt both before and after the strike.

An explanation for this void was provided almost twenty years ago by Craig (1988), when he argued that theories and learnings from organizational psychology/behaviour have largely been overlooked in industrial relations. Similarly that same year, Barling (1988) argued that the organizational psychology/behaviour field had largely ignored issues relevant to industrial relations. Since that time, we have seen efforts to bridge this gap (Barling, Fullagar, and Kelloway, 1992) and specific research concerning employee affect (e.g., satisfaction and commitment) in unionized workplaces, but the latter has usually examined whether unionized employees have higher (or lower) affect than non-unionized employees (Freeman and Medoff, 1984; Hammer and Avgar, 2005). Clearly, learnings from the field of organizational psychology/behaviour are critical to the topic of the impact 
of strikes, particularly as they relate to worker reactions. Thus, the present study investigated the impact of a strike on measures traditionally used in the organizational psychology/behaviour literature, namely, job satisfaction, management satisfaction, organizational commitment, work climate satisfaction, and union commitment. In the following section, we review the literature related to these measures.

Job and Management Satisfaction. Job satisfaction is considered to be at the corner stone of organizational psychology/behaviour as it is one of the most frequently studied dependent variables in that field (Brief and Weiss, 2002; Latham and Pinder, 2005). Job satisfaction can be defined as a positive emotional reaction to one's assessment of one's job experience (Locke, 1976). In a recent study, Saari and Judge (2004) found the nature of the work, supervision, job responsibilities, and co-worker relationships all contribute to the level of job satisfaction. These findings are consistent with the past work of Smith, Kendall and Hulin (1969) who developed a measure of job satisfaction examining these preceding factors. Job satisfaction is significant within the context of the present study because one could assume that after a strike, the work situation (such as job responsibilities, co-worker relationships and the nature of the work) would change, thus, potentially altering job satisfaction. Moreover, given that the relationship with the immediate supervisor could change immensely after a strike, we examined the facet of management satisfaction on its own. This decision to examine both job and management satisfaction is consistent with past research concerning workplace justice in unionized settings (Fryxell and Gordon, 1989). However, to our knowledge, no study has focused on how direct involvement in a strike can impact either overall job satisfaction or the specific facet of management satisfaction. Yet, based on the previous conceptualization of satisfaction, we could see how satisfaction could increase (i.e., due to wage gains) or decrease (i.e., due to tension with management) as a result of a strike.

Organizational Commitment. There is a long history of research concerning organizational commitment in the organizational psychology/ behaviour literature, with one paper finding almost 1000 studies on the topic (Cooper-Hakim and Viswesvaran, 2005). According to Vakola and Nikolaou (2005), building on the seminal work of Mowday, Steers and Porter (1979), organizational commitment can be characterized by three related aspects: acceptance of the organization's goals and values; exertion of a substantial amount of effort on behalf of the organization, and aspiration to remain a member of the organization. Organizational commitment is important in the workplace as a recent meta-analysis found a positive relationship between organizational commitment and both job satisfaction and performance, as well as a negative relationship between organizational 
commitment and turnover (Cooper-Hakim and Viswesvaran, 2005). Overall, these results suggest that organizations where employees have high levels of organizational commitment will see positive employee reactions and performance. Given that going on strike can be seen as a sign of disengagement from the company, one could predict that organizational commitment would decrease during a strike. However, to our knowledge, no study has examined whether a strike could negatively impact one's commitment to the organization.

Work Climate Satisfaction. Patterson et al. (2005) outlined the importance of organizational climate. Reflecting upon a study conducted by Brown and Leigh (1996), Patterson et al. (2005) indicated that if the work environment was perceived to be motivating, and the organization was thought to be involved, performance ratings were mainly positive. This can be further substantiated by a recent study (Pomeroy, 2005). That study indicated that favourable perceptions of work climate were associated with high levels of customer service, individual performance and employee retention. Thus we expected that a positive work environment would be associated with higher employee affect (e.g., commitment and satisfaction).

As discussed earlier in this paper, a strike can result in strained workplace relationships, tension, verbal abuse, etc. (see Herald, 2002; Nicholson and Kelly, 1980). As such, one could predict that satisfaction with work climate could decrease following a strike. Yet, we can find no study that tests this relationship.

Union Commitment. Researchers (Kuruvilla, Gallagher and Wetzel, 1993; Snape, Redman and Chan, 2000) associate union commitment with organizational commitment. These researchers indicate several antecedents to union commitment by using the 'parallels model', which suggests that commitment to the union can be studied and based on previous organizational commitment research such as Mowday, Steers and Porter's (1979) organizational commitment questionnaire. In fact, Snape, Redman and Chan (2000), following their review of the literature, concluded that commitment to the employing organization facilitates union commitment. Moreover, when the IR climate is perceived to be positive, commitment to the union and the employer are both positive. What can be gleamed from these results is that the actors of the IR system do not compete for worker commitment and that a favourable work climate can have positive implications for both actors.

However, what is missing from previous research is how union commitment is affected by a strike. Do members become increasingly committed to the union after a strike, or does their commitment to the union decrease or remain the same? One could assume that in the event of a strike, the IR climate becomes less positive and therefore, union commitment may 
decrease. Alternatively, one could predict that the commitment to the union may increase post-strike, especially if gains were made as a result of the strike. However, this temporal relationship has not been specifically examined, and we hope to fill this gap in the union commitment literature.

The literature reviewed reveals that organizational commitment, job satisfaction, work climate, management satisfaction and union commitment are important variables to our field. However, there has been limited examination of how these preceding organizational psychology/behaviour variables can be impacted by a strike. One study measured several of these variables (e.g., job satisfaction, organizational commitment, union commitment, organizational climate) two months after a three-week strike in an effort to assess the relationships and the predictors of organizational and union commitment (Barling, Wade and Fullagar, 1990). Among the findings of that study were that tenure was a positive predictor of union commitment and that union commitment and organizational commitment were negatively correlated. A limitation of that study was that no pre-strike measures of any kind were examined.

A second study (Barling et al., 1992) examined the relationship between organizational commitment, union loyalty (i.e., commitment) and the propensity of union members to strike (i.e., how likely one would support a strike). This study found that union loyalty was associated with propensity to strike. However, this study did not examine an actual strike: it only examined propensity to strike.

A third study examined how union and organizational commitment could be impacted during the course of a university faculty contract negotiation, through an assessment of pre-negotiation and post-negotiation commitment (Beauvais, Scholl, and Cooper, 1991). A limitation of that study is that it did not examine a work stoppage.

A fourth study examined the relationship between union and organizational commitment during a Korean strike (Lee, 2004). A limitation of that study was that it only examined members' current level of commitment; thus, the temporal element was not considered.

Additional studies have examined how nurses reacted to a physicians' strike (Carmel et al., 1988; Shoham-Yakubovich et al., 1989). These studies had employees assess their job satisfaction during and post-strike using a single survey. They found that a physicians' strike increased nurses' job satisfaction, likely due to increased job autonomy. Limitations of these studies are that the nurses were not on strike.

In summary, we found limited research concerning what we feel is a critical IR issue, namely, the extent that employee affect (in terms of their perception of organizational commitment, job satisfaction, work climate 
satisfaction, management satisfaction and union commitment) can be impacted by a strike. More specifically, research has not considered the temporal effect of a strike, namely, do employees perceive their workplace more or less favourably (in terms of these affect measures) when they reflect on how they felt pre-strike versus how they felt post-strike? Thus, our goal was to assess the extent that a strike impacts these perceptions using measures collected after a strike, while also examining the potential of temporal effects through the use of retrospective questions measuring pre-strike reactions. Whether workers' assessments of pre and post-strike reactions were 'free of bias' was not key for us in this study. Previous research has established that individuals' perceptions influence their behaviours, attitudes, and well-being (e.g., Frese and Zapf, 1988). Thus, as our aim was to focus on whether, based on workers' reflections, worker reactions towards their union, their employer and their workplace changed following the strike, assessing worker perceptions of affect was most appropriate in this study.

\section{METHODS}

\section{Sample}

In order to control for extraneous effects, we surveyed employees impacted by a single strike. This decision was consistent with past research (Barling et al., 1990, 1992; Carmel et al., 1988; Shoham-Yakubovich et al., 1989). Specifically, we surveyed union members of a North-American telecommunications company ${ }^{1}$ who encountered a five-month long strike. The key unresolved issues that led to the job action pertained to salary increases, pensions, and job security. After a five-month strike, an agreement was reached with the aid of mediators. The climate during the strike was somewhat strained with allegations of striking employees engaging in sabotage behaviour.

In total, approximately 4300 employees within several different bargaining units were involved in the dispute. One of these local bargaining units within the union was chosen for the sample. This particular unit consisted of approximately 700 union members working in several communities in one province, thus facilitating the distribution of surveys. Workers were surveyed approximately 8 months after the strike had occurred.

1. Note that the names of neither the union nor the firm are reported as the researchers assured the union that the union and company would not be named in the final paper. 


\section{Procedure}

The survey procedure used in this study was modified from that of Bemmels, Reshef, and Stratton-Devine (1991) and Bemmels (1994) in that we distributed surveys to the union executive of the union at their annual executive meeting. These executive members, in turn, distributed the surveys to the union members in each of their corresponding regions within the province. In total, there were approximately 700 employees, provincewide in the union. This single survey asked respondents to assess their pre and post-strike reactions. Respondents then returned their anonymous surveys directly to the research team (at their university address) using a prepaid postage envelope attached to each survey. As an anonymous survey was used, we could not tell who had, or had not, completed surveys. As such, no personalized reminder letters were sent to those who had not completed surveys. Rather, approximately 10 days after the surveys had been distributed, the union sent an electronic message, through its e-mail system, to all members encouraging them to complete surveys if they had not already done so.

\section{Key Measures}

Key measures in this study were job satisfaction, organizational commitment, work climate satisfaction, management satisfaction and union commitment. Based on the counsel of the union (and to ensure that the survey was manageable), we adapted the following measures rather than using all items from the original scales. This decision is consistent with other survey research in unionized settings where scales have been modified to reduce survey length (Bemmels, Reshef and Stratton-Devine, 1991, Shrerer and Morishima, 1989), with some researchers using only single measures of employee affect (e.g., Fryxell and Gordon, 1989).

Job satisfaction was adapted from Smith, Kendall and Hulin's (1969) Job Descriptive Index and was assessed using 8-items and a 7-point scale ( 1 = Strongly Disagree, 7 = Strongly Agree). Sample items included "My job is satisfying" and "Other employees were unpleasant to work with (reverse-scored)."

Organizational commitment was measured using 10-items adapted from Mowday, Steers and Porter (1979). We specifically chose that measure given its similarity to the union commitment measure used in the present study. Sample items included "Deciding to work for (name of firm) was a mistake on my part (reverse-coded)" and "This is the best possible organization to work for." Again, the preceding 7-point-likert scale was used.

Work climate satisfaction was measured using five items adapted from Newman's (1975) perceived work environment measure. Sample items 
included "There is little tension between co-workers and management" and "I feel pressured to complete my job tasks (reverse-scored)." Each item was assessed using a 5-point scale where $1=$ Not at all True and $5=$ Very True.

Management satisfaction was adapted from the "supervision on present job" component of Smith, Kendall and Hulin (1969). Participants assessed 10 items using a scale of $1=$ Strongly Disagree to $5=$ Strongly Agree. Sample items included: "Management does not accept my advice (reversecoded)" and "Management does not praise my work (reverse-coded)".

Union commitment was adapted from the scale of Gordon et al. (1980). They showed that union commitment was comprised of four dimensions: (1) union loyalty, (2) responsibility to the union, (3) willingness to work for the union, and (4) belief in unionism. Our measure contained questions representing the first three dimensions as Gordon et al. (1980) found that the fourth dimension accounted for the least variance in their factor analysis and overlapped heavily with dimension one. We also included two questions adapted from Angle and Perry (1986) as the union was interested in: (a) whether members agreed with the union policies, and (b) members' views concerning the long-term survival of the union. The final measure included 10 items, assessed on a 5-point scale where $1=$ Not at All and $5=$ Very Much So. Sample items included "I am willing to put a great deal of effort into making the union successful" and "I feel very little loyalty toward the union (reverse coded)".

\section{RESULTS}

\section{Preliminary Analysis}

Preliminary analysis included analysis of response rate and participant demographics, recoding of reverse items, and an assessment of the reliability of our key measures (i.e., Cronbach's alpha).

Given that surveys were distributed via the union executive, an exact response rate cannot be calculated. Of the approximately 700 surveys that were distributed, 187 surveys were returned for an estimated response rate of $26.71 \%$. This estimated response rate would appear to be consistent with other studies of Canadian union members, where response rates were near 30\% (Barling et al., 1990, 1992) and above that of other studies using the same distribution process, where response rates were in the 18-24\% range (Bemmels, 1994; Bemmels, Reshef and Stratton-Devine, 1991). The typical respondent was a 42.07 year old $(\mathrm{sd}=8.81)$ female $(59.6 \%)$ with 17.67 ( $\mathrm{sd}=9.56$ ) years tenure. As an anonymous survey was used, we could not assess whether survey respondents and non-respondents differed on 
demographic measures. However, members of the union executive assured us that the demographics of our 'typical' respondent are representative of their membership.

Prior to assessing the reliabilities of the scales, reverse-ordered items were recoded in the appropriate manner. Cronbach's alpha for each of the five scales, for both the pre-strike and post-strike measures, was examined to ensure the scales were reliable. The majority of the measures were reliable with Cronbach's alpha of .70 or better. However, one of the scales, namely, work climate after the strike, obtained a Cronbach's alpha below 0.70. As dropping variables did not improve the scales's reliability, we left the measure unchanged. The Cronbach's alphas, means, and standard deviation of each scale are presented in Table 1.

TABLE 1

Summary of Key Scales

\begin{tabular}{lccc}
\hline \multicolumn{1}{c}{ Scale/Measure } & Alpha & Mean & $\begin{array}{c}\text { Standard } \\
\text { Deviation }\end{array}$ \\
\hline Organizational Commitment Pre-strike & .88 & 45.44 & 13.57 \\
Organizational Commitment Post-strike & .89 & 33.03 & 12.95 \\
Job Satisfaction Pre-strike & .73 & 38.92 & 8.15 \\
Job Satisfaction Post-strike & .70 & 33.80 & 8.32 \\
Work Climate Pre-strike & .76 & 17.21 & 4.14 \\
Work Climate Post-strike & .62 & 13.57 & 3.94 \\
Management Satisfaction Pre-strike & .90 & 29.32 & 8.53 \\
Management Satisfaction Post-strike & .90 & 24.39 & 8.96 \\
Union Commitment Pre-strike & .91 & 30.69 & 9.95 \\
Union Commitment Post-strike & .90 & 23.25 & 9.94 \\
\hline
\end{tabular}

Following the assessment of reliability, two-tailed Pearson correlations were conducted for each of the measures (see Table 2). Note that we did not include age in the table as age and tenure were highly correlated $(r=.85$, $p<.001)$ and because we felt that tenure, given the implications of seniority in a unionized workplace, was the more salient variable. Overall, results indicated that the measures of job satisfaction, organizational commitment, and management satisfaction and work climate generally correlated significantly with one another. However, union commitment, in particular the post measure, did not correlate with several reaction measures. There were, however, significant correlations between pre-union commitment and pre-management satisfaction $(r=-.14, p<.06)$, post-organizational 


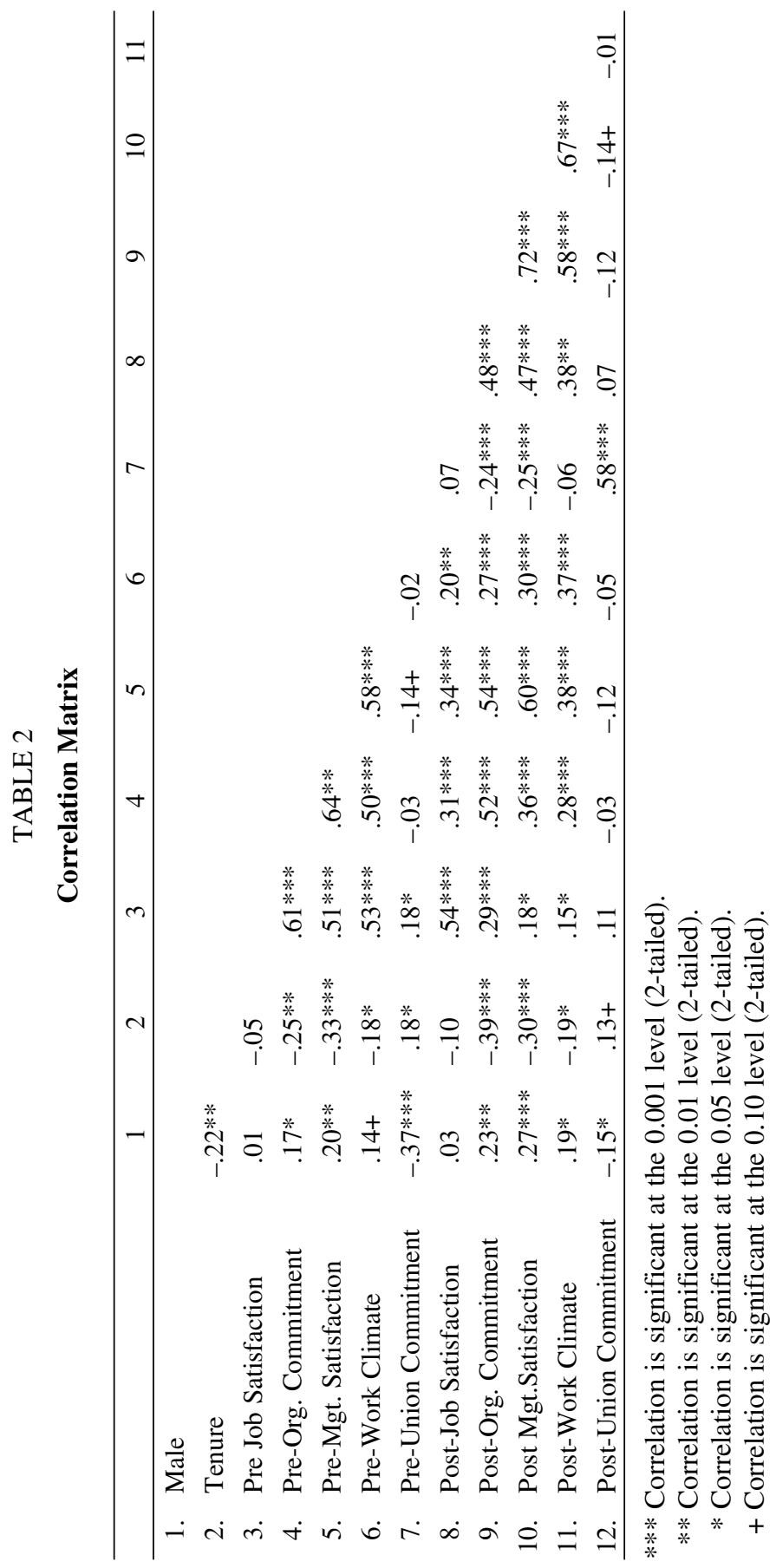


commitment $(r=-.24, p<.001)$, pre-job satisfaction $(r=.18, p<.05)$ and post-management satisfaction $(r=-.25, p<.001)$. Interestingly, the only significant correlation for post-strike union commitment (among reaction measures) was negative with post-management satisfaction ( $r=-.14, p<.06)$, suggesting that employees with high satisfaction with their management, had low commitment to their union (and viceversa).

A review of demographic measures reported in this table further reveals that, in general, more senior employees (i.e., those with high tenure) had more negative affect across most measures except union commitment, both pre- and post-strike, compared to younger workers. Sex also played a role, as being male was generally associated with higher affect towards management (i.e., male correlated positively with management satisfaction and organizational commitment) and lower affect towards the union (i.e., male was negatively correlated with union commitment).

Given that satisfaction with work climate is argued to play an important role in the relationship between union and organizational commitment, we ran partial correlations between both pre-measures (i.e., pre-organizational commitment and pre-union commitment) and post-measures, controlling for the appropriate work climate satisfaction measure. The results revealed no relationship for the pre-measures $(r=-.03, p>.05)$ and a significant partial correlation for the post-measures $(r=-.14, p=.05)$. Thus, when controlling for work climate, there was a negative correlation between the union and organizational commitment measures following the strike.

\section{Secondary Data Analysis: Paired Sample T-tests}

As stated earlier, we grounded our argument that strikes could impact worker reactions on Craig's IR systems model. To assess whether there was a difference in the five reaction measures following a strike, we compared the retrospective pre-strike value to the post-strike value using paired t-tests. Specifically, each paired t-test examined the same measure to determine if there was a statistically significant difference between the pre and post measures. The results of the paired t-tests are presented in Table 3.

Results indicate that all the retrospective values representing before strike means were all significantly higher than the after strike means $(p<.001)$. This suggests that the level of organizational commitment, job satisfaction, work climate satisfaction, management satisfaction and commitment toward the union all, in the eyes of respondents, decreased following the strike. As such, these results suggest that a lengthy strike can potentially have a negative impact on a broad range of worker reactions towards their union and their organization. 
TABLE 3

Paired Sample T-Tests

\begin{tabular}{lcc}
\hline & $\begin{array}{c}\text { Paired Difference } \\
\text { Mean }(\text { sd })\end{array}$ & T-value \\
\hline $\begin{array}{l}\text { Pair 1: } \\
\text { Organizational Commitment Before } \\
\text { Organizational Commitment After }\end{array}$ & $12.28(13.00)$ & $12.88^{* * *}$ \\
$\begin{array}{l}\text { Pair 2: } \\
\text { Job Satisfaction Before }\end{array}$ & $5.11(7.93)$ & $8.82^{* * *}$ \\
Job Satisfaction After & & \\
Pair 3: & $3.64(4.53)$ & $10.99^{* * * *}$ \\
Work Environment Before & & \\
Work Environment After & & \\
Pair 4: & $4.93(7.80)$ & \\
Management Satisfaction Before & & $13.65^{* * * *}$ \\
Management Satisfaction After & & \\
Pair 5: & & \\
Union Commitment Before & & \\
Union Commitment After & & \\
\hline
\end{tabular}

*** All paired differences significant at the 0.001 level (2-tailed)

\section{Secondary Data Analysis: Regression}

Precious research has found that worker affect can differ based on tenure and sex (Sherer and Morishima, 1989). Given the significant correlations between tenure and sex in the correlation table, we examined whether the relationships revealed by the paired t-tests could be impacted by member demographics. As such, we ran a series of exploratory regressions where each of the five post-affect measures represented a dependent variable, with the retrospective pre-strike equivalent measure, tenure and sex being independent variables. ${ }^{2}$ The results are presented in Table 4.

The results revealed no significant effects for sex or tenure on job satisfaction (see Table 4A); however, tenure had a negative relationship with organizational commitment (see Table 4B). In contrast, sex (i.e., male) had a positive relationship with management satisfaction (see Table 4C). For the work climate regression (see Table 4D), we again saw a negative coefficient for tenure and a positive coefficient for male, but the results were not significant. Our analysis of union commitment also did not reveal

2. Note we also ran the regressions including an interaction term (tenure $x$ sex). As none of the interaction terms were significant, and as the results were largely unchanged, the regressions including interaction terms are not presented for space reasons. 
TABLE 4

\section{Regression Results}

\begin{tabular}{|c|c|c|c|c|}
\hline & Coefficient & S.E. & $t$-statistic & Significance \\
\hline \multicolumn{5}{|c|}{ A: Post-Strike Job Satisfaction as Dependent Variable } \\
\hline Pre-Strike Job Satisfaction & .55 & .07 & $8.33 * * *$ & .00 \\
\hline Male & .10 & 1.13 & .09 & .93 \\
\hline Tenure & -.06 & .06 & -1.06 & .29 \\
\hline Constant & 13.17 & 3.53 & $3.73 * * *$ & .00 \\
\hline Sample Size & 177 & & & \\
\hline F-Statistic & $\begin{array}{c}23.85 \\
(\operatorname{sig}=.000)^{* * *}\end{array}$ & & & \\
\hline Adjusted $\mathrm{R}^{2}$ & .28 & & & \\
\hline \multicolumn{5}{|c|}{ B: Post-Strike Organizational Commitment as Dependent Variable } \\
\hline Pre-Strike Org. Commitment & .42 & .06 & $6.83 * * *$ & .00 \\
\hline Male & 2.72 & 1.69 & 1.61 & .11 \\
\hline Tenure & -.35 & .09 & $-3.98 * * *$ & .00 \\
\hline Constant & 15.96 & 4.47 & $3.57 * * *$ & .00 \\
\hline Sample Size & 177 & & & \\
\hline F-Statistic & $\begin{array}{c}30.82 \\
(\operatorname{sig}=.000)^{* * *}\end{array}$ & & & \\
\hline Adjusted $\mathrm{R}^{2}$ & .34 & & & \\
\hline \multicolumn{5}{|c|}{ C: Post-Strike Management Satisfaction as Dependent Variable } \\
\hline Pre-Strike Mgt. Satisfaction & .56 & .07 & $8.45 * * *$ & .00 \\
\hline Male & 2.55 & 1.13 & $2.27 *$ & .03 \\
\hline Tenure & -.90 & .06 & -1.50 & .14 \\
\hline Constant & 5.24 & 3.06 & $1.71+$ & .09 \\
\hline Sample Size & 177 & & & \\
\hline F-Statistic & $\begin{array}{c}36.36 \\
(\operatorname{sig}=.000)^{* * *}\end{array}$ & & & \\
\hline Adjusted $\mathrm{R}^{2}$ & .38 & & & \\
\hline \multicolumn{5}{|c|}{ D: Post-Strike Work Climate as Dependent Variable } \\
\hline Pre-Strike Work Climate & .31 & .07 & $4.47 * * *$ & .00 \\
\hline Male & .93 & .58 & 1.60 & .11 \\
\hline Tenure & -.05 & .03 & -1.56 & .12 \\
\hline Constant & 7.56 & 1.67 & $4.52 * * *$ & .00 \\
\hline Sample Size & 177 & & & \\
\hline F-Statistic & $\begin{array}{c}10.65 \\
(\operatorname{sig}=.000)^{* * *}\end{array}$ & & & \\
\hline Adjusted $\mathrm{R}^{2}$ & .14 & & & \\
\hline \multicolumn{5}{|c|}{ E: Post-Strike Union Commitment as Dependent Variable } \\
\hline $\begin{array}{l}\text { Pre-Strike Union } \\
\text { Commitment }\end{array}$ & .50 & .06 & $8.91 * * *$ & .00 \\
\hline Male & 1.47 & 1.01 & 1.45 & .15 \\
\hline Tenure & .03 & .05 & 61 & .54 \\
\hline Constant & 4.73 & 2.91 & 1.62 & .11 \\
\hline Sample Size & 176 & & & \\
\hline F-Statistic & $\begin{array}{c}28.68 \\
(\operatorname{sig}=.000)^{* * *}\end{array}$ & & & \\
\hline Adjusted $\mathrm{R}^{2}$ & .32 & & & \\
\hline
\end{tabular}

\footnotetext{
*** significant at the 0.001 level

** significant at the 0.01 level

* significant at the 0.05 level

+ significant at the 0.10 level
} 
significant effects. Overall, the results presented in Table 4 suggest that demographic variables, namely sex and tenure, may play a role in helping us understand how employees react to strikes.

\section{CONCLUSION}

A goal of this study was to examine the extent to which worker's are impacted by strikes, and more specifically, the extent to which strikes impact reactions in terms of how workers perceived their organizational commitment, management satisfaction, work climate satisfaction and union commitment when they reflected on how they felt pre-strike versus poststrike. Several implications flow from the results of the present study.

First, as pointed out in the introduction, Craig's IR system suggests that strikes, whether they be considered conversion mechanisms or outputs of the system, impact employee reaction. The present results support for this argument. Our findings suggest that worker reaction, as measured by five measures taken from the organizational behaviour/psychology literature, may be significantly, and in this case negatively, impacted by a strike. From a theoretical perspective, the results demonstrate the importance of Craig's feedback loop in the IR system, as well as the need to include variables concerning worker reaction in our teaching, research, and application of both IR systems in general, and strikes in particular.

Second, the study builds on the work of Barling et al. (1992) in that we further bridge the gap between the industrial relations and organizational psychology/behaviour literatures. We used measures from the latter to examine a critical IR issue-employee reaction to a strike. Moreover, the study is the first, to our knowledge, to examine the extent to which a strike results in a potential change in workers' perceived reaction towards their job, their union, their manager and their workplace. As such, the present results suggest that the time is ripe for additional cross-pollination between these two disciplines.

Third, we believe this study has significant practical implications for several actors of the IR system. As noted earlier, the paired t-tests found that employee reaction towards their job, workplace, management and union all appeared to drop after a strike. Bearing in mind the results concerning the decreases in satisfaction and organizational commitment discussed in our literature review, management could anticipate that those who responded will not perform job tasks as productively or efficiently as they did pre-strike. Furthermore, the previously presented literature reveals that employees who have low satisfaction and low commitment are more likely to leave an organization. With this in mind, given low levels 
of job satisfaction and organizational commitment measures post-strike, management could anticipate that turnover may increase.

An important implication for the union is that, in the eyes of union members, their level of union commitment is lower post-strike as revealed by the paired t-tests. Given the linkages between union commitment and union involvement (Thacker, Fields and Barclay, 1990), we can argue that, post-strike, the union leaders may experience less active members. Moreover, given the decrease in their commitment levels post-strike, members may not be as supportive of the union's goals and values and, furthermore, may be reluctant to remain members.

The results of this study also have important implications for workers. In addition to the lower levels of the attitudinal measures, these workers were impacted and, in some cases, disenchanted by this strike. A number of surveys were returned to the research team with additional comments expressing how upset some employees were as a result of the strike and its outcomes. These workers expressed their frustrations towards both the union and management. Clearly, this would suggest that the time to 'heal the wounds' post-strike may be considerable. A future research study may wish to examine what actions management and/or labour can take to both narrow the gap between these pre- and post- strike reaction measures and expedite the 'recovery' process.

Fourth, our results suggest that demographic factors should play a role in future research in this area. The general trend was that affect towards the company (i.e., management satisfaction, work climate, satisfaction and organizational commitment) was more positive for men than women. In addition, longer tenure was associated with more negative affect towards the employer on these same variables and more positive affect to the union. Future research should now test whether the present results are idiosyncratic.

As is the case for all research, there are several limitations to the present research study. Firstly, there is non-response bias. While our response rate is consistent with past studies of union members (Barling et al., 1990, 1992; Bemmels, 1994; Bemmels, Reshef and Stratton-Devine, 1991), and the union assured us that our sample is demographically representative, we cannot rule out the possibility that our respondents were not in some way significantly different from non-respondents. For example, was it employees who reacted the most negatively to the strike that responded to our survey? Alternatively, any changes in employee reaction may have been underrepresented as the response rate may have contributed to a Type II error due to sample size and lack of power. One potential explanation for nonresponse bias in the present study was the fact that the management team of this particular organization distributed an attitudinal survey to employees 
shortly (i.e., approximately a month) before this research study began. A second explanation may be our survey distribution method. Note that our survey was distributed in early June, after the annual union executive meeting, and at the start of vacation period.

A second potential limitation of this study, as is the case with many survey studies, is common method variance. While the correlation matrix (Table 2) does show a number of insignificant correlations, suggesting that common method variance is not a problem in the current study, this possibility cannot be ruled out.

A third limitation is the lack of true pre-measures. All respondents answered survey questions after the strike had occurred, even though a number of the survey questions pertained to how employees felt before the strike. Thus, one can argue that the retrospective pre-measures used may not be accurate, that respondents may have a biased view as they are answering questions for two different time periods, and that respondents may have been influenced by current circumstances and, subconsciously, have based their prior-strike feelings on how they felt presently, which could flaw the results.

Our decision in this regard was influenced by three factors. First, it is often not possible to assess these measures pre-strike, as it is not always possible to know when a strike will occur. Moreover, if organizations and unions expect a strike, they may be reluctant to survey workers believing that it may 'add fuel to the fire', particularly as such methods would require the identification and matching of an individual's pre-strike and poststrike reactions. In fact, as previously discussed, we found a single paper (Beauvais, Scholl and Cooper, 1991) that assessed pre-negotiation and post-negotiation commitment measures. It was conducted in an academic setting, where a strike did not occur, and where the relationship between the parties was relatively positive (i.e., one, short strike in a 20 -year period). Arguably, the context of a university setting, where faculty have 'the right' to conduct research, would make a survey of such a sensitive issue more acceptable in that environment relative to a traditional private or public sector setting. Second, the use of retrospective questions is consistent with other survey research conducted after a strike where participants were asked to rate how they felt during and post-strike (Carmel et al., 1988; ShohamYakubovich et al., 1989). Third, our purpose was not to statistically test whether a true change in affect occurred, but rather, whether workers' own reactions differed when they recalled how they felt pre-strike versus how they felt post-strike.

Nevertheless, the results are clear. A comparison of pre-strike and poststrike reactions suggests that, in the eyes of employees, things have become worse. As evidenced by the paired t-tests, workers perceived the strike as 
having a negative impact. For the purposes of this study, it is the issue of employee perception that 'things got worse' that is more salient than if their reactions were valid, particularly given: (a) the data in our literature review showing the well-documented negative relationship between these worker reaction measures and both organizational and worker well-being, and (b) the IR systems' inclusion of a feedback loop suggesting that outputs, such as strikes, can have future implications on the actors of the system.

There are several different avenues to explore when considering further research within this area of IR. First of all, if possible, measuring employee reactions prior to a strike, during the bargaining process, during a strike, and after a strike would be an outstanding contribution to research. This type of research would eliminate the aforementioned limitation of using retrospective questions. A longitudinal study of this sort would zero in on participants' reactions at the exact time in question; thus, the data collected would be a true reflection. This type of study would also reveal the extent to which worker reaction may change during particular stages of the bargaining and dispute process. Moreover, such research could be augmented with a control group of non-striking workers employed at the same location.

Another area for further research would be to examine multiple strikes. The present study focused on a single strike and its impact on the employment relationship in terms of worker affect. However, an examination of several different strikes may uncover similar or different results. This again highlights the need for additional research in this area.

\section{】 REFERENCES}

Angle, Harold L. and James L. Perry. 1986. "Dual Commitment and LaborManagement Relationship Climates." Academy of Management Journal, 29 (1), 31-50.

BARLING, Julian. 1988. "Industrial Relations: A Blind Spot in the Teaching, Research and Practice of I/O Psychology." Canadian Psychology, 29 (1), 103-108.

BARLING, Julian and Jill MiLligan. 1987. "Some Psychological Consequences of Striking: A Six Month, Longitudinal Study." Journal of Occupational Behavior, 8 (2), 127-137.

BARLING, Julian, Bill Wade and Clive Fullagar. 1990. "Predicting Employee Commitment to Company and Union: Divergent Models." Journal of Occupational Psychology, 63 (1), 49-61.

Barling, Julian, Clive Fullagar, and E. Kevin Kelloway. 1992. The Union and Its Members: A Psychological Approach. Oxford: Oxford University Press.

Barling, Julian, Clive Fullagar, E. Kevin Kelloway and Leanne McElvie. 1992. "Union Loyalty and Strike Propensity." Journal of Social Psychology, 132 (5), 581-590. 
BeAuvais, Laura L., Richard W. Scholl and Elizabeth A. CoOPer. 1991. "Dual Commitment among Unionized Faculty: A Longitudinal Investigation." Human Relations, 44 (2), 175-192.

Bemmels, Brian. 1994. "The Determinants of Grievance Initiation.” Industrial and Labor Relations Review, 47 (2), 285-301.

Bemmels, Brian, Yonatan Reshef and Kay Stratton-Devine. 1991. "The Roles of Supervisors, and Stewarts in Grievance Initiation." Industrial and Labor Relations Review, 45 (1), 15-30.

BRIEF, Arthur P. and Howard M. WeIss. 2002. "Organizational Behavior: Affect in the Workplace." Annual Review of Psychology, 53 (1), 279-307.

Brown, Steven P. and Thomas W. Leigh. 1996. "A New Look at Psychological Climate and its Relationship to Job Involvement, Effort, and Performance." Journal of Applied Psychology, 81 (4), 358-368.

CAmpolieti, Michele, Robert Hebdon and Douglas Hyatт. 2005. "Strike Incidence and Strike Duration: Some New Evidence from Ontario." Industrial and Labor Relations Review, 58 (4), 610-630.

CARmel, Saram, Ilana Shoham-Yakubovich, Lea Zwanger and Tsila Zaltcman. 1988. "Nurses Autonomy and Job Satisfaction." Social Science and Medicine, 26 (11), 1103-1107.

COOPER-HAKIM, Amy and Chockalingam Viswesvaran. 2005. "The Construct of Work Commitment: Testing an Integrative Framework." Psychological Bulletin, 131 (2), 241-259.

Craig, Alton W. J. 1967. "A Model for the Analysis of Industrial Relations System." Paper presented to the Annual Meeting of the Canadian Political Science Association.

CraIG, Alton W. J. 1988. "Mainstream Industrial Relations in Canada." The State of the Art in Industrial Relations. G. Hébert, H. C. Jain and N. Meltz, eds. Toronto: Canadian Industrial Relations Association, Queen's University Industrial Relations Centre, and the Centre for Industrial Relations, University of Toronto, 9-43.

Craig, Alton W. J. and Norman A. Solomon. 1996. The System of Industrial Relations in Canada. $5^{\text {th }}$ edition. Toronto, ON: Prentice Hall Canada.

Cramton, Peter C. and Joseph S. Tracy. 1994. "The Determinants of U.S. Labor Disputes." Journal of Labor Economics, 12 (2), 180-209.

DunLoP, John T. 1958. Industrial Relations System. Boston, Mass.: Harvard Business School Press.

Franzosi, Roberto. 1989. "One Hundred Years of Strike Statistics: Methodological and Theoretical Issues in Quantitative Strike Research." Industrial and Labor Relations Review, 42 (3), 348-362.

Freeman, Richard B. and James Medoff. 1984. What Do Unions Do? New York: Basic Books.

FRESE, Michael and Dieter ZAPF . 1988. "Methodological Issues in the Study of Work Stress: Objective vs. Subjective Measurement of Work Stress and the Question of Longitudinal Studies." Causes, Coping, and Consequences of Stress at Work. C. L. Cooper and R. Payne eds. Chichester: Wiley, 375-411. 
FryXell, Gerald E. and Michael E. Gordon. 1989. "Workplace Justice and Job Satisfaction as Predictors of Satisfaction with Union and Management." Academy of Management Journal, 32 (4), 851-866.

Gordon, Michael E., John W. PhILPOT, Robert E. Burt, Cynthia A. ThOMPSON and William E. SPILLER. 1980. "Commitment to the Union: Development of a Measure and an Examination of its Correlates." Journal of Applied Psychology, 65 (4), 479-499.

Gunderson, Morley, Allen Ponak and Daphne Taras. 2005. UnionManagement Relations in Canada. $5^{\text {th }}$ ed. Toronto, ON: Pearson Education Canada.

Gunderson, Morley, Bob Hebdon, Douglas Hyatt and Allen Ponak. 2005. "Strikes and Dispute Resolution." Union-Management Relations in Canada. $5^{\text {th }}$ ed. M. Gunderson, A. Ponak and D. Taras, eds. Toronto, ON: Pearson Education Canada, 332-370.

Hammer, Tove H. and Ariel Avgar. 2005. "The Impact of Unions on Job Satisfaction, Organizational Commitment, and Turnover." Journal of Labor Research, 26 (2), 241-266.

HEBDON, Robert and Travor C. BRown. 2007. Industrial Relations in Canada. Scarborough, ON: Nelson Thompson.

Herald, Don. 2002. "Back to Work Doesn't Mean Back to Normal." Canadian HR Reporter, 15 (15), 8-9.

Kuruvilla, Sarosh, Daniel G. Gallagher and Kurt Wetzel. 1993. "The Development of Members' Attitudes toward their Unions: Sweden and Canada." Industrial and Labor Relations Review, 46 (3), 499-514.

Latham, Gary P. and Craig C. Pinder. 2005. "Work Motivation Theory and Research at the Dawn of the Twenty-First Century." Annual Review of Psychology, 56 (1), 485-516.

LEE, Jiman. 2004. "Company and Union Commitment: Evidence from an Adversarial Industrial Relations Climate at a Korean Auto Plant." International Journal of Human Resource Management, 15 (8), 1463-1480.

LOCKE, Edwin A. 1976. "The Nature and Causes of Job Satisfaction." Handbook of Industrial and Organizational Psychology. Chicago: Rand McNally, 1319-1328.

Meltz, Noah M. and Roy J. AdAms. 1993. Industrial Relations Theory: Its Nature, Scope, and Pedagogy. Rutgers University: Scarecrow Press.

Mowday, Richard T., Richard M. Steers and Lyman W. Porter. 1979. "The Measurement of Organizational Commitment." Journal of Vocational Behavior, 14 (2), 224-247.

Newman, John E. 1975. "Understanding the Organizational Structure: Job Attitude Relationship through Perceptions of the Work Environment." Organizational Behavior and Human Performance, 14 (3), 371-397.

NichOLSON, Nigel and John Kelly. 1980. "The Psychology of Strikes." Journal of Occupational Behavior, 1 (4), 275-284.

Patterson, Malcom G., Michael A. West, Viv J. Shackleton, Jeremy F. Dawson, Rebecca Lawthom, Sally MaitLis, David L. Robinson and Allison 
M. Wallace. 2005. "Validating the Organizational Climate Measure: Links to Managerial Practices, Productivity and Innovation." Journal of Organizational Behavior, 26 (4), 379-408.

PeirCe, Jon and Karen J. Bentham. 2007. Canadian Industrial Relations. $3^{\text {rd }}$ ed. Toronto, ON: Pearson Education Canada.

Pomeroy, Ann. 2005. "Climate Control.” HR Magazine, 50 (5), 18.

RAO, Karthik, A. 2000. "The Impact of Strikes on Current Employment Statistics." Monthly Labor Review, 123 (8), 32-40.

SAARI, Lise M. and Timothy A. Judge. 2004. "Employee Attitudes and Job Satisfaction." Human Resource Management, 43 (4), 395-407.

SHERER, Peter D. and Motohiro Morishima. 1989. "Roads and Roadblocks to Dual Commitment: Similar and Dissimilar Antecedents of Union and Company Commitment." Journal of Labor Research, 10 (3) 311-330.

SHOHAM-YAKUBOVICH, Ilana, Sara CARMEL, Lea ZwANGER and Tsila ZALTCMAN. 1989. "Autonomy, Job Satisfaction and Professional Self-Image Among Nurses in the Context of a Physicians' Strike." Social Science and Medicine, 28 (12), 1315-1320.

Smith, Patricia C., Lorne M. Kendall and Charles L. Hulin. 1969. The Measurement of Satisfaction in Work and Retirement. Chicago, Ill.: RandMcNally.

Snape, Ed, Tom Redman and Andy Chan. 2000. "Commitment to the Union: A Survey of Research and the Implications for Industrial Relations and Trade Unions." International Journal of Management Reviews, 2 (3), 205-230.

ThaCKer, James W., Mitchell W. FIELDS and Lizabeth A. BARClAY. 1990. "Union Commitment: An Examination of Antecedent and Outcome Factors." Journal of Occupational Psychology, 63 (1), 33-48.

VAKOLA, Maria and Ioannis NiKOLAOU. 2005. "Attitudes towards Organizational Change: What is the Role of Employees' Stress and Commitment?" Employee Relations, 27 (2), 160-174.

WeINBERG, Sharon. L. and Sarah. K. ABrAmowitz. 2002. Data Analysis for the Behavioral Sciences using SPSS. Cambridge, U.K.: Cambridge University Press.

\section{RÉSUMÉ}

\section{Une évaluation de la réaction après-grève des travailleurs à l'égard de leur syndicat et de leur employeur : une expérience canadienne}

Le cadre de référence d'analyse des systèmes de relations industrielles proposé d'abord par Dunlop (1958) demeure le cœur de l'enseignement et de la recherche de l'approche «système » de Craig (1967, voir également Craig et Solomon, 1996). Ce dernier s'inspire du cadre de référence des 
systèmes de Dunlop et il a été intensément utilisé pour l'étude des enjeux des relations du travail au Canada (voir Gunderson, Ponack et Taras, 2005). Dans le modèle de Craig, on se souvient que les grèves et les lockouts sont considérés comme des mécanismes de conversion d'intrants en extrants. Comme tel, Craig suggère qu'une grève est un mécanisme retenu pour convertir des intrants internes, tels que des objectifs, des valeurs et du pouvoir, en extrants ou en résultats de caractère organisationnel, tels que la reconnaissance du syndicat, la négociation de l'effort à fournir contre rémunération et la sécurité d'emploi. De plus, le modèle de Craig démontre que ces résultats se relient en retour aux intrants externes par le biais d'une boucle de rétroaction, créant ainsi un flux d'effets qui retournent dans le système des relations industrielles. Ce qui importe le plus, c'est que le modèle indique qu'une grève exerce un impact sur les relations et l'environnement de travail partagés par les acteurs du système de relations industrielles. Alors, une grève exerce une influence sur la relation d'emploi.

Encore qu'une grande part du travail de recherche et d'enseignement eu égard aux grèves a abordé les enjeux d'ordre économique et politique associés aux grèves (voir les revues effectuées par Gunderson et al., 2005, Franzosi, 1989). Un effort plutôt limité de recherche dans le domaine des relations industrielles s'est intéressé aux enjeux psychologiques inhérents aux grèves. Il est évident que l'enseignement en psychologie organisationnelle ou en sciences du comportement adopte une position critique à l'endroit d'un sujet tel que l'impact d'une grève, plus précisément celui qui traite des réactions des travailleurs. Alors, cette étude-ci a analysé l'effet d'une grève en recourant à des mesures habituellement retenues dans le domaine de la psychologie organisationnelle, principalement celles qui servent à apprécier le degré de satisfaction au travail, de satisfaction à l'endroit de la direction, le degré d'implication organisationnelle, le degré de satisfaction quant au climat de travail, enfin le degré d'engagement syndical.

Des questionnaires ont été expédiés à environ 700 membres d'un syndicat qui ont pris part à une longue grève de cinq mois dans le secteur des communications. Des membres du syndicat $(\mathrm{n}=187)$ ont complété le questionnaire en se prononçant sur cinq types d'échelles : l'engagement à l'endroit de l'organisation, la satisfaction au travail, la satisfaction quant au climat de travail, la satisfaction à l'endroit de la direction et l'engagement syndical, cela huit mois après la grève. Nous avons demandé aux participants de répondre à deux ensembles de questions pour chacune des mesures, principalement sur la manière dont ils voyaient les choses actuellement et comment ils voyaient les choses avant la grève. Les deux mesures avant et après la grève ont été prises au cours d'une seule et même enquête.

Des tests « $\mathrm{t} »$ arrangés par paires ont permis de constater que la grève avait un impact négatif sur les réactions des travailleurs à la fois à l'endroit 
du groupe des dirigeants et de leur syndicat sur les cinq mesures. Des analyses de régression additionnelles et exploratoires sur les cinq mesures (en retenant l'ancienneté, le genre et une mesure prégrève appropriée) suggèrent que les travailleurs de sexe masculin et les plus jeunes font part de réactions plus positives que les femmes et les travailleurs plus âgés. La conclusion pratique de cet essai est que les effets négatifs des grèves peuvent se transposer (et ils le font) dans le lieu de travail en termes de réactions d'un travailleur à l'endroit de son syndicat et de son employeur. D'un point de vue théorique, les conclusions de ce travail permettent de croire que les travaux de recherche effectués sur la grève et les modèles retenus devraient être élargis de façon à inclure l'examen d'enjeux liés à la réaction des travailleurs. 